\title{
The Economic Impact of Malaysia's Institution on the Failure of the Wawasan 2020
}

\author{
XU Jianing \\ Journalism, Xiamen University Selangor, Sepang, 43900, Malaysia
}

\begin{abstract}
On the arrival of 2020, Malaysian President Mahathir officially announced the failure of Wawasan 2020, which is also called Vision 2020. This article discusses the cause of this failure from the perspective of institutional issues, namely political struggle, institutional corruption, supreme Malay policy. At the same time, this article puts forward the following opinions for the future economic development of Malaysia because of the above issues. The first thing to govern is the corruption of government officials and the corruption of the system. Secondly, the government should improve its unfair education system and reduce the drain of Chinese talents. Taking the Korean economy as an example, Malaysia can achieve a win-win situation with China through the Belt and Road Initiative.
\end{abstract}

\section{INTRODUCTION}

In 1991, the fourth Prime Minister of Malaysia Mahathir Mohamad proposed the Wawasan 2020, which can also be called as Vision 2020. One of the essential visions called for Malaysia to become a developed country by the year 2020 . Time flies in a blink of an eye, 2020 has arrived. Two years ago, Dr. Mahathir became the leader of the country once again, the seventh prime minister of Malaysia. However, the current economic situation of Malaysia is far from what he promised thirty years ago. The Wawasan 2020 has failed. This paper aims to investigate how Malaysia's institutions contributed to the failure of the "Vision 2020". For the subsequent development, the opportunities for Malaysia to become a developed country will also be addressed.

\section{BACKGROUND}

On February 8th, 1991, Dr Mahathir read out the Vision 2020 that the government would develop the economy with the goal of "becoming an industrialized developed country in 2020". The vision aimed to reach an \$12,000 national income per capital by 2020 , compared to 2,400 at that time. In 1990, Malaysia only got a GDP of RM115 billion, and Dr. Mahathir targeted the GDP at a value of RM 920 billion through the planned annual economic growth rate of $7 \%$.

\section{ISSUES}

There are many reasons for the annual growth rate of Malaysia's GDP not meeting expectations. In addition to the external blow from the 2008 economic crisis, institutional issues within Malaysia have negatively impacted the realization of Vision 2020.

\subsection{Politic Uncertainty}

Firstly, the unstable political situation brought about by the political struggles in Malaysia over the years have greatly affected its economic development. In the early stages of the Vision 2020, relations among the ethnic groups in Malaysia were relatively stable from 1990 to 2005 . At that time, both government and the people unanimously pursued the Vision 2020. However, this harmonious coexistence did not last long. In 2005, United Malays National Organization (UMNO), which is the founder and largest party of the National League of National Front, leaned to the political right. UMNO emphasizes the racial status of the Malays and highlights inter-ethnic differences. UMNO continues to incite inter-ethnic conflicts, which has led to more and more people marching on the streets. The fierce struggle for power has left the government with neither time nor energy to develop the Malaysian economy. As the country faces political turmoil, meaningful fiscal measures will be greatly delayed supporting the economy, even if those measures have been announced as planned.

Apart from party struggles between different races, the struggle of party leaders for the presidency seems more severe. To fight for power, national leaders framed slander with each other and devised various political traps about sex scandals. As political figures in an Islamic country, Malaysian dignitaries have even used sodomy charges as a weapon for political struggle more than once. In Malaysia's political history, Mahathir is considered to be the originator of this political tactic. From 1998 to 2018, two "Sodomy Sex" attacks against Anwar have affected the outcome of the ongoing government's confrontation. Political 
instability will reduce the predictability of future policies and it will also bring difficulties to active investment plans or consumption plans. In terms of consumption, concerns about the sustainability of the social security system will increase precautionary savings and lead to a sluggish consumer spending. In the early 1990s, Professor Robert Joseph Barro of Harvard University pointed out that indicators of political instability such as revolution and assassination would have a negative impact on economic growth and investment.

People seemed to have left the consensus of Wawasan 2020 behind. Once political leaders cannot adhere to principles, too many immoral transactions will occur, and they will be easily bought and changed positions, and democratic politics will be very vulnerable.

\subsection{Corruption}

Once political leaders fail to adhere to principles, unethical transactions can easily occur. Government officials can easily change their positions for money, which would make democracy more fragile. According to New Times Strait, corruption is securitized as the most serious threat and number one enemy. Corruption has become a common phenomenon among Malaysian government officials, and the Malay government's fiscal loopholes and external debt have become increasingly severe.
The corruption and inaction of the former government led by Najib caused a severe setback in Malaysia's economy. The highest historical value of Malaysian government debt appears on September 1, 2016, reaching 229.74 billion ringgits. In 2015, Najib was accused by the opposition party of transferring funds from a Malaysian company under the jurisdiction of the Malaysian government into his personal bank account, involving a bonus of $\$ 700$ million. This led the previous administration to be involved in a $\$ 4.5$ billion corruption scandal, 1Malaysia Development Berhad scandal, which can be considered as the most significant theft case by the U.S. Department of Justice. The U.S. Department of Justice alleges that the Malaysian company's leaders and their associates stole US \$ 4.5 billion from Malaysian companies between 2009 and 2014, while laundering money through the global financial system, including the United States. According to the US Department of Justice's complaint, Liu Tezuo is the main brain of the entire money laundering scheme. The complaint also named other people, including Liu Tezuo's friend and Prime Minister Najib 's step=-son Riza, several leaders of the Malaysian company, and Najib 's own "Malaysian officer No.1". This case revealed the extent of Malaysia's corruption and misappropriation of public funds. With huge external debt and corruption within the government, Malaysia will face the challenge of fiscal austerity in the next few years.

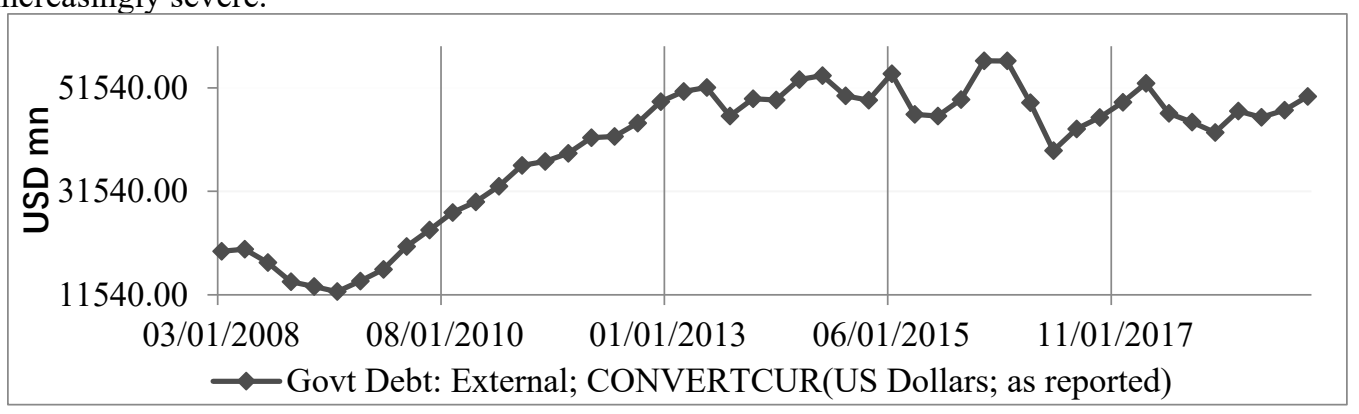

Figure 1. Malaysia 's external government debt in 2008-2018

In addition to the high external debt due to the government corruption, Najib government also failed in their promise on GDP growth. Najib presented the "Eleventh Malaysian Plan" in 2015 and promised that if the GDP of Malaysia could reach 5\% to $6 \%$ per year, Malaysia can still reach the "2020 Vision" and become a developed country. However, the Pakatan Harapan government led by Dr. Mahathir reviewed the "Eleventh Malaysia Plan" in 2018 with a disappointing result.

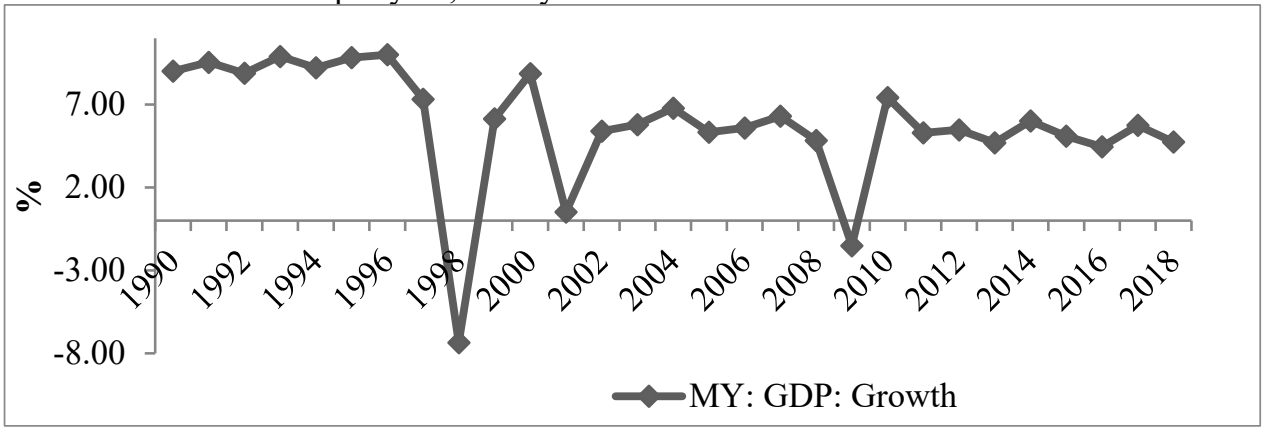

Figure 2. Malaysia 's GDP Growth

\subsection{Malay Supremacy Policies}

Another big issue in Malaysia is ethnic inequality that has led to the Malay supremacy policies. This policy was originally designed to close the economic gap and achieve social balance among the multiracial population. The government tries to eliminate poverty and redistribution of wealth in order to achieve equality among different races.

The background of this policy starts from 1957, when Malaysia was in a period of negotiating independence. Malaysia is at a level of extreme poverty, while the Chinese who do business in Malaysia occupy most of the country's 
trade and economic transactions. As such, the Malaysia delegate advises Chinese and Indians to settle in Malaysia to help stabilize the national economy. The condition is then to implement this Malay-first policy to close the economic divide between Malays and other races. In this agreement, the Malays have absolute economic advantages. For example, cheap houses are reserved for indigenous peoples, and some shares need to be allocated to them.

Although a series of policies centered on the Malay supremacy has achieved certain income distribution equality, these unfair policies have dealt a heavy blow to the Chinese. The Chinese merchants who are unable to reap the benefits consistent with their returns due to the Malay policy, so they choose to leave. The proportion of Malaysian Chinese has fallen from nearly $40 \%$ in 1957 to around $20 \%$ in 2017.

Apart from ethnic and welfare differences in business and life, Malaysia has also implemented a racial quota system based on Malay interests in education. For example, certain government universities are only open to indigenous peoples, and non-indigenous admission rates by government universities are extremely low (Article 153 of the Constitution of Malaysia). Of the pre-university classes admitted by the Ministry of Education in 2018/2019, $87 \%$ of the students are Malay, Indians account for $7.57 \%$, and Chinese account for only $4.91 \%$.

Most Malaysian government scholarships for overseas studies are awarded to Malays. In terms of admissions to public universities, the Malaysian authorities also use ethnicity as a reason to allocate professional fields such as medicine, engineering, law, pharmacy and biotechnology to Malays. Even if the outstanding Chinese students have achieved outstanding results, they may not be able to enter the ideal university successfully [1]. This principle of Malay supremacy is not only reflected in policy but has also become a basic concept of Malaysians. Malays don't need to work as hard as Chinese to make a living, because they enjoy all kinds of social benefits given by the government. Even without a job, Malays receive a living allowance. The implementation of these policies will have a certain degree of negative impact on Malaysia's current and future economic development.

Malaysia favors the protection of the Malays, which has led to overreliance on the Malays. They do not need to study and work as hard as the Chinese in Malaysia to enjoy better treatment than them. However, the Malay population in Malaysia It accounts for nearly $70 \%$, which means that their dependence on the government will cause the country's economic competitiveness to decline.

In 2019, Dr Mahathir participated in a conference called "Malay Dignity". As the name suggested, it was a conference to discuss ethnic issues. The most shocking thing is that the rally was sponsored by four government universities, including the best university in Malaysia, the University of Malaya. It is conceivable that the young generation of Malay has been infused with this Malay supremacy.

It is confusing that the Prime Minister insisted that the conference had nothing to do with race. However, it can be learned from the seven appeals made in the conference that the purpose of this rally is to limit non-indigenous and non-Muslims and to promote Malay supremacy. One of the appeals requires the government to ensure that all Chinese primary and secondary schools are eliminated within six years. At the same time, only Malay primary and secondary schools are retained. Malaysia's Malay population accounts for about $70 \%$. With the continuous development of the Malay Supreme Policy, the proportion of Malays will increase, which means that they will represent Malaysia's main competitiveness. Under Malaysia's current policy, a new generation of young people will gradually lose their world competitiveness, both in education and policy. The government's excessive protection of them, that is, their dependence on the government, will cause the country's economic competitiveness to decline.

The Malay supremacy in Malaysia is still apparent. Prime Minister Dr Mahathir was once an anti-Chinese racist and vigorously advocated that "Chinese cannot hold high government positions because the Chinese hold most of Malaysia 's wealth". In 2018, Dr Mahathir started to be aware of the severe corruption within the first ruling party dominated by the Malays and the outflow of Chinese talent and wealth. For this reason, the opposition party he led united the Chinese. However, after the new government came into power, reforms have not been implemented. Race disputes have repeatedly heated up, and the education system has not been improved well.

\section{OPPORTUNITIES AND SUGGESTIONS}

Although the political uncertainty, government corruption and the racial inequality policy have a negative impact on Malaysia's economy, Malaysia was still developing steadily. Under the disadvantage of political instability, the recent data show that Malaysia's economic still keep steady and grow slightly.

The continuous development of Malaysia is inseparable from its unique conditions. Peninsular Malaysia enjoys a unique geographical location. It is close to the Malacca Strait, which is one of the most important economic and political transportation routes in the world. With its geographical location, Malaysia has been able to transform its economy from agricultural and mining bases in the early 1970 s to more competitive industries. These highly competitive middle-income countries' services and manufacturing industries now account for $75.8 \%$ of Malaysia's GDP[3].

According to the National Bank data, the main highlights of Malaysia's economic development are as follows. Since 2000, Malaysia 's annual real GDP growth has averaged 5.5\%, and Malaysia has maintained an overall stable inflation rate of 0.7 to $1.7 \%$ [2]. At the same time, the national income per capita is growing by nearly $6 \%$ annually. In the World Bank's Global Business Environment Report 2019, Malaysia ranked 15th in the ease of doing business among the 190 economies surveyed, which is an increase from its 24th ranking in 2018. These figures show that Malaysia's economy still has potential for development. 


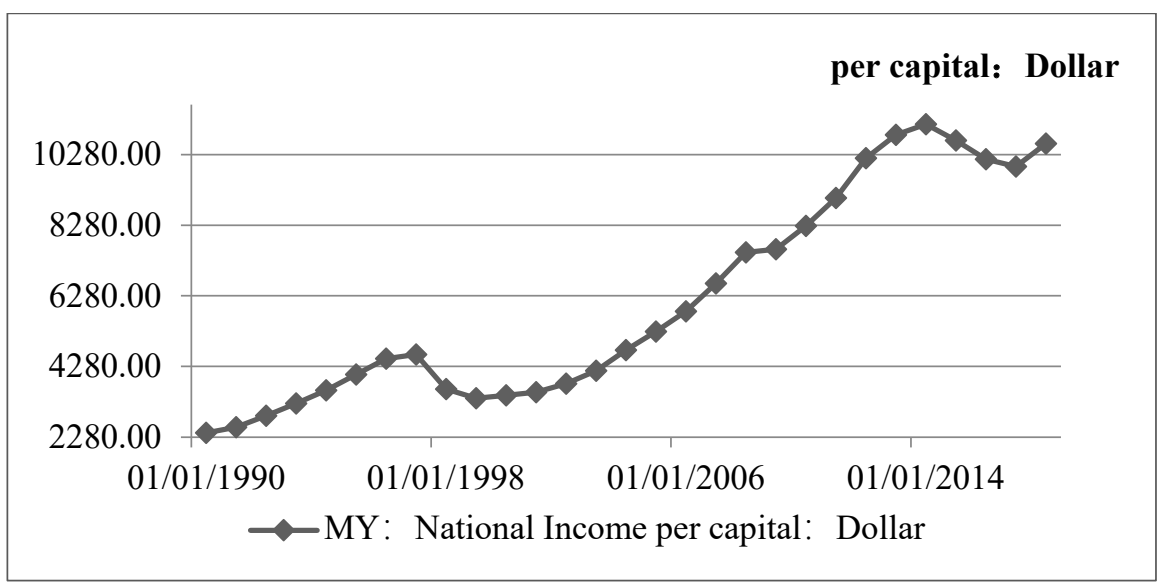

Figure 3. Malaysia 's National Income in 1990-2014

At the end of 2019, Dr Mahathir acknowledged the failure of Vision 2020 and proposed Vision 2030. If Malaysia still intends to become a high-income country, it will be crucial to increase productivity in the next decade continuously. Although economic development has been very successful over the past two decades, productivity growth has not met expectations and has even stagnated in recent years. Increased productivity can help people increase their average income and improve their living standards[4].Several vital elements can increase productivity in Malaysia.

\subsection{Fight Corruption}

The priority is to improve governance and fight corruption. If national government corruption is severe, it will undermine a country's ability to attract employees and investors[5]. This is also the focus of work pointed out by the current Malaysian government in the election statement. The Pakatan Harapan government introduced the following methods to attack the corruption left by the previous government. In 2018, the government established the National Center for Governance Integrity and Anti-Corruption, which proposed new methods to improve procurement processes and eliminate conflicts of interest. In January 2019, the government launched a new anti-corruption plan that focuses on increasing transparency in financial transactions and strengthening regulatory capacity. However, this is not enough. The institutional corruption in Malaysia is not only a problem of the previous government but a legacy of many years. There is still a need to continue to sort out and clean up corruption within the country.

\subsection{Quality Education}

Another element is investing in quality education. Although the resources invested in education have improved significantly over the past two decades, the effects have not been fully realized. However, as mentioned earlier, the improvement of education is still under the premise of Malay supremacy. This biased university admission method will lead to the continuous loss of Chinese talent.

In other aspects, the Malays have obtained significant advantages, but everyone should be equal in education. Colleges should choose based on merit. At the same time, the government could increase funding for lifelong learning and skills retraining projects. Investing in quality education can reduce skills mismatches, raise wages and help all citizens take advantage of the potential of new technologies.

On March 1st, 2020, Muhyiddin bin Yassin, chairman of the Indigenous Solidarity Party, became the eighth Prime Minister of Malaysia. Muhyiddin once said in an interview with British News that Malaysia should give priority to Malays. While he was in the role of Minister of Education, he announced that the government primary and secondary schools would resume using Malay to teach mathematics, which abolished the English teaching policy pursued during Mahathir term.

Therefore, people still doubt the new president's political attributes, especially his attitude towards pluralism and liberal politics. The lack of minority representation in the new government is even more worrying.

As Prime Minister, Muhyiddin must understand that he is leading a multi-ethnic, multi-religion-based country, which is also the foundation of Malaysia. Muhyiddin must consider the collective future of this country, adopt an enlightened and modest ruling line, and strive for universal support. Only national unity and reduced brain drain can continue to promote the development and prosperity of the country's economy.

\section{CONCLUSION}

In general, the impact of the Malaysian Institution on the Vision 2020 is mainly attributed to the following three points: political uncertainty, government corruption and the Malay paramount policy. Surprisingly, though under the negative influence of this policy, the economy still maintains a certain degree of steady growth. Although Malaysia did not achieve the Vision 2020, the data in recent years have shown its good economic performance. If Malaysia can actively improve its institutional and political image, it will have inestimable economic development. On the one hand, Malaysia is a place for investors to consider. On the other hand, the investors need to be alert to the changes in the government of Malaysia and the issuance of new policies when investing. 


\section{ACKNOWLEDGMENT}

First and foremost, I would like to show my deepest gratitude to my teachers and professors in my university, who have provided me with valuable guidance in every stage of the writing of this thesis. Further, I would like to thank all my friends and roommates for their encouragement and support. Without all their enlightening instruction and impressive kindness, I could not have completed my thesis.

\section{REFERENCES}

1. R. Barghi, Z. Zakaria, A. Hamzah, N. H. Hashim. Heritage education in the primary school standard curriculum of Malaysia. Teaching and Teacher Education, 2017, vol. 61, pp.124-131.

2. D. Fleming, H. Søborg. Can Vision 2020 be far away? Malaysia's transformation problems to a high-income economy. Global Policy, 2019, vol.10, no. 4, pp.512-526.

3. A.X.Y. Mah, W.S. Ho, C.P.C. Bong, M.H. Hassim, P.Y. Liew, U.A. Asli, et al. Review of hydrogen economy in Malaysia and its way forward. International Journal of Hydrogen Energy. 2019

4. M.F. Montes, J. Cruz. The political economy of foreign investment and industrial development: the Philippines, Malaysia and Thailand in comparative perspective. Journal of the Asia Pacific Economy,2020, vol.25, no.1, pp. 16-39.

5. S.W. Olawale. External debt, corruption, and economic growth in selected five Sub-Saharan African countries. Universiti Utara Malaysia, 2017. 